\title{
Distribution of an APP Homolog, APLP2, in the Mouse Olfactory System: A Potential Role for APLP2 in Axogenesis
}

\author{
Gopal Thinakaran, ${ }^{1,5}$ Cheryl A. Kitt, ${ }^{1,5}$ A. Jane I. Roskams, ${ }^{2}$ Hilda H. Slunt, ${ }^{1,5}$ Eliezer Masliah, ${ }^{7}$ Cornelia von \\ Koch, ${ }^{2,5}$ Stephen D. Ginsberg, ${ }^{1,5}$ Gabriele V. Ronnett, ${ }^{1,4}$ Randall R. Reed,, ${ }^{2,3,6}$ Donald L. Price, ${ }^{1,2,4,5}$ and Sangram \\ S. Sisodia' ${ }^{1,5}$ \\ 1Departments of Pathology, ${ }^{2}$ Neuroscience, ${ }^{3}$ Molecular Biology and Genetics, and ${ }^{4}$ Neurology, ${ }^{5}$ Neuropathology \\ Laboratory, and the ${ }^{6}$ Howard Hughes Medical Institute, The Johns Hopkins University School of Medicine, \\ Baltimore, Maryland, 21205 and 7 Departments of Neurosciences and Pathology and Neuroscience, University of \\ California at San Diego, La Jolla, California 92093
}

Deposition of $\beta$-amyloid $(A \beta)$ in senile plaques is a major pathological characteristic of Alzheimer's disease. $A \beta$ is generated by proteolytic processing of amyloid precursor proteins (APP). APP is a member of a family of related polypeptides that includes amyloid precursor-like proteins APLP1 and APLP2. To examine the distribution of APLP2 in the nervous system, we generated antibodies specific for APLP2 and used these reagents in immunocytochemical and biochemical studies of the rodent nervous system. In this report, we document that in cortex and hippocampus, APLP2 is enriched in postsynaptic compartments. In the olfactory system, however, APLP2 is abundant in olfactory sensory axons, and axon terminals in glomeruli. Confocal microscopy revealed that APLP2 is present in both pre- and postsynaptic compartments in the olfactory bulb. Notably, mRNA encoding chondroitin sulfate glycosaminoglycan (CS GAG)-modified forms of APLP2 are enriched in the olfactory epithelium, relative to alternativelyspliced mRNA, encoding CS GAG-free forms of APLP2. In addition, we demonstrate that CS-modified APLP2 forms accumulate in the olfactory bulb. CS proteoglycans are known to play an important role in regulating cell migration and neuronal outgrowth. Since sensory neurons in the olfactory epithelium are in a state of continual turnover, axons of newly generated cells must establish synaptic connections with neurons in the olfactory bulb in adult life. The presence of APLP2 in olfactory sensory axons and glomeruli is consistent with the view that this protein may play an important role in axonal pathfinding and/or synaptogenesis.

[Key words: amyloid precursor-like protein 2, APP,

\footnotetext{
Received Apr. 3, 1995; revised May 22, 1995; accepted May 31, 1995.

The CT12 peptide was obtained from the Protein Sequencing and Peptide Synthesis Core maintained by the Center for AIDS Research at Johns Hopkins University School of Medicine under Contract Number 1P30 A128748 from the National Institute for Allergy and Infectious Diseases of the NIH. We thank Drs. Samuel Gandy, Mike Lee, and Philip Wong for providing antibodies 369, TuJ1, and Myc-I, respectively; Karen Schrader for providing mouse olfactory epithelium RNA; Dr. David Borchelt for providing APP-695 cDNA; and Dr. Wilma Wasco for providing the APLP1 cDNA. This work was supported by grants from the NIA, NINDS, American Health Assistance Foundation, Alzheimer's Association, and the Adler Foundation.

Correspondence should be addressed to Dr. Sangram S. Sisodia, The Johns Hopkins University School of Medicine, Neuropathology Laboratory, 558 Ross Research Building, 720 Rulland Avenue, Ballimore, MD 21205-2196.

Copyright (c) 1995 Society for Neuroscience 0270-6474/95/156314-13\$05.00/0
}

APLP2, alternative splicing, chondroitin sulfate glycosaminoglycan, glomeruli, olfactory epithelium, olfactory sensory neurons]

A principal pathological feature of Alzheimer's disease is the deposition of $A \beta$ in brain parenchyma (Glenner and Wong, 1984; Masters et al., 1985). $A \beta$, an $\sim 4 \mathrm{kDa}$ polypeptide, is derived from larger type I integral membrane glycoproteins, termed the amyloid precursor proteins (APP) (Kang et al., 1987; Kitaguchi et al., 1988; Ponte et al., 1988; Tanzi et al., 1988; Golde et al., 1990; König et al., 1992). APP is a member of a family of homologous amyloid precursor-like proteins (APLPs), including APLP1 (Wasco et al., 1992) and APLP2 (Sprecher et al., 1993; Wasco et al., 1993; Slunt et al., 1994). Although the members of this gene family share considerable homology in the amino- and carboxyl-terminal domains, the APLPs differ from APP by the absence of the $A \beta$ region.

At present, APLP2 is the best characterized member of APLPs. Like APP, APLP2 is encoded by several mRNAs derived by alternative splicing (Wasco et al., 1993; Sandbrink et al., 1994; Slunt et al., 1994). Both APP and APLP2 are expressed in brain and peripheral tissues (Wasco et al., 1993; Slunt et al., 1994), and in situ hybridization studies disclose similarities in the distributions of APP and APLP2 mRNAs in mouse (Slunt et al., 1994) and human (Wasco et al., 1993) CNS. Finally, APLP2 matures through the same unusual secretory/cleavage pathway as APP (Slunt et al., 1994). However, in contrast to APP-695 and APP-751/770, APLP2-751 is a substrate for modification by a single CS GAG chain (Thinakaran and Sisodia, 1994).

In this study, we report on the distribution of APLP2 in the rodent nervous system using newly generated antibodies specific for APLP2. Consistent with previous in situ hybridization studies (Slunt et al., 1994), our investigations with the APLP2-specific antibodies revealed that APLP2 is expressed in a variety of regions, including cerebral cortex, hippocampus, and thalamus. Confocal microscopy revealed prominent colocalization of APLP2 with MAP-2, a postsynaptic marker, in cortex and hippocampus. Moreover, APLP2 mRNA is highly expressed in sensory neurons in the olfactory epithelium, and the encoded polypeptide is abundant in olfactory sensory axons, and axon terminals in glomeruli. In contrast to its predominant postsynaptic localization in ncurons in cortex and hippocampus, APLP2 is present in both pre- and postsynaptic compartments in the ol- 
factory bulb. Notably, mRNA encoding CS GAG-modified forms of APLP2 are highly represented in the olfactory epithelium, and CS GAG modified forms of APLP2 accumulate in the olfactory bulb. Since olfactory sensory neurons are continually turned over, axons of newly generated neurons must establish synaptic connections with neurons in the olfactory bulb in adult life. Taken together with the view that CS proteoglycans play an important role in regulating cell migration and neuronal outgrowth (for review, see Wight et al., 1992), the unique localization of APLP2 in olfactory sensory axons and glomeruli is consistent with the notion that this protein may play an important role in axonal pathfinding and/or synaptogenesis.

\section{Materials and Methods}

Antibodies. Ab369 is a polyclonal antibody raised against the entire cytoplasmic domain (residues 645-694) of APP-695 (Buxbaum et al., 1990), and was kindly provided by Dr. Samuel Gandy (Cornell University Medical College, New York). c-Myc-modified APLP2 polypeptides (Thinakaran and Sisodia, 1994) were immunoprecipitated using polyclonal antiserum Myc-I (provided by Dr. Philip Wong, Department of Pathology, The Johns Hopkins University School of Medicine, Baltimore), raised against the synthetic peptide MEQKLISEEDLN (Lee et al., 1993).

To generate polyclonal APLP2-specific antibody CT12, a synthetic peptide corresponding to the C-terminal 12 amino acids (residues 740751) of mouse APLP2-751 with an additional cysteine at the $\mathrm{N}$-terminus (CNPTYKYLEQMQI) was coupled to maleimide-activated keyhole limpet hemocyanin (Imject, Pierce Chemical Co., Rockford, IL). The conjugate was purified by gel filtration and subsequently injected into New Zealand White rabbits. Polyclonal antibodies D2-I and D2-II were raised in two separate rabbits using full-length mouse APLP2-751 synthesized in Sf9 cells as the antigen, as described previously (Thinakaran and Sisodia, 1994).

Purification of CT12, D2-I, and D2-II antibodies. For immunocytochemical studies, we prepared an IgG fraction of CT12 antibody using a Protein A agarose affinity column (Pierce Chemical Co., Rockford, IL). D2-I and D2-II antibodies were affinity purified on a column containing a glutathione $S$-transferase (GST)-APLP2 fusion protein. Briefly, sequences that encode residues 562-681 of mouse APLP2-751 (Slunt et al., 1994) were generated by PCR and subcloned into plasmid pGEX2T (Smith and Johnson, 1988). The resulting plasmid, pGEX $\triangle$ APLP2, encodes a fusion of GST with a 120 amino acid region of APLP2-751 which occurs immediately $\mathrm{N}$-terminal to the transmembrane domain. The GST fusion protein (GST $\triangle A P L P 2)$ was expressed in bacteria and immobilized onto glutathione agarose beads as described (Smith and Johnson, 1988). For affinity purification, an IgG fraction of the D2-I or D2-II antiserum was incubated at $4^{\circ} \mathrm{C}$ for $16 \mathrm{hr}$ with glutathione agarose beads containing bound GST $\triangle$ APLP2. The beads were washed twice in a buffer containing $50 \mathrm{mM}$ Tris- $\mathrm{HCl}(\mathrm{pH} 7.5)$ and $0.3 \mathrm{M} \mathrm{NaCl}$. Bound antibodies were eluted with $2 \mathrm{ml}$ of $100 \mathrm{~mm}$ glycine- $\mathrm{HCl}(\mathrm{pH} \mathrm{2.5)}$ and neutralized.

Plasmid construction. To generate $\mathrm{pEF} 695$, an expression construct containing the mouse APP695 cDNA, plasmid pFLAPP (provided by Dr. Bruce T. Lamb, Department of Gynecology and Obstetrics, The Johns Hopkins University School of Medicine, Baltimore) was incubated in a polymerase chain reaction with sense primer $5^{\prime}$-CCGCTCGAGACGATGCTGCCCAGCTTGG-3', antisense primer 5'-CCGCTCGAGGCTTAGTTCTGCATTTGCTC-3' and a third primer 5'-CGCCTGGACCTGGAGAATTACATCATCGC- $3^{\prime}$ in order to modify the internal XhoI site. The PCR product was digested with XhoI and the APP cDNA fragment was ligated to an unique SalI site in a modified pEFBOS vector (Mizushima and Nagata, 1990). Plasmids pSVAPLP1 and pSVAPLP2 which contain the mouse APLP1 and APLP2-75.1 cDNA, respectively, placed downstream of the SV40 promoter/enhancer were generated as follows. Sequences encoding mouse APLP1 were excised from a Bluescript vector (Wasco et al., 1992; kindly provided by Dr. Wilma Wasco, Harvard Medical School) and inserted in a pUC 19-based vector from p770SP (Sisodia et al., 1990). The APLP2 cDNA insert was isolated from plasmid pD2 (Slunt et al., 1994), and ligated to a vector molecule derived from plasmid p770SP (Sisodia et al., 1990).

Transfection, immunoprecipitation, and Western blot analysis. COS-1 cells, an African green monkey kidney line, were transiently transfected in 60 Inum plates with $10 \mu \mathrm{g}$ of $\mathrm{CsCl}$-purified plasmid DNA using a high-efficiency calcium phosphate method (Chen and Okayama, 1987). Thirty-six hours after transfection, cells were labeled with $200 \mu \mathrm{Ci} / \mathrm{ml}$ ${ }^{30}$ S-methionine (Du Pont NEN, Wilmington, DE) for $3 \mathrm{hr}$ in Dulbecco's modified Eagle medium lacking methionine and supplemented with $1 \%$ dialyzed fetal calf serum. Detergent lysates and conditioned medium prepared from labeled cells were subject to immunoprecipitation analysis as described (Sisodia et al., 1990; Slunt et al,, 1994). CT12, D2-I, and D2-II antibodies were used at 1:2500 dilution for Western blot analysis of lysates prepared from cells transiently expressing APP, APLP1, or APLP2.

In situ hybridization. Sequences that encode residues 568-681 of mouse APLP2 were cloned into Bluescript $\mathrm{KS}^{+}$(Slunt et al., 1994) and used as templates to generate sense or antisense ${ }^{33} \mathrm{P}$-labeled riboprobes using a RNA transcription kit (Stratagene, La Jolla, CA). Sections (10 $\mu \mathrm{m})$ cut from fixed frozen mouse nasal epithelium were dried onto slides coated with Fol's mounting medium, fixed in $4 \%$ paraformaldehyde (PFA) for $20 \mathrm{~min}$ and rinsed in phosphate-buffered saline (PBS) and deionized water. After acetylation in $0.25 \%$ acetic anhydride prepared in $0.1 \mathrm{M}$ triethanolamine, sections were rinsed in PBS and dehydrated through a graded series of alcohol, and then dried. Sections were hybridized overnight at $55^{\circ} \mathrm{C}$ in a buffer containing $50 \%$ formamide, $10 \%$ dextran sulfate, $0.3 \mathrm{M} \mathrm{NaCl}, 20 \mathrm{~mm}$ Tris (pH 7.5), $10 \mathrm{mM}$ DTT, $5 \mathrm{~mm}$ EDTA, $1 \times$ Denhardt's solution and $0.4 \mathrm{mg} / \mathrm{ml}$ yeast tRNA, and $1 \mathrm{ng} / \mathrm{slide}$ of labeled probe $\left(\sim 2 \times 10^{6} \mathrm{cpm} / \mathrm{ng}\right)$. Slides were washed as follows: $5 \times \mathrm{SSC}(1 \times \mathrm{SSC}=0.15 \mathrm{M} \mathrm{NaCl}, 0.015 \mathrm{M}$ sodium citrate $)$ and $1 \mathrm{mM} \mathrm{DTT}$ at $55^{\circ} \mathrm{C}$ for $20 \mathrm{~min} ; 50 \%$ formamide, $2 \times \mathrm{SSC}$ and 1 $\mathrm{mM}$ DTT at $60^{\circ} \mathrm{C}$ for $30 \mathrm{~min} ; 10 \mathrm{~mm}$ Tris (pH 7.5), $0.5 \mathrm{M} \mathrm{NaCl}$, and 5 mM EDIA (TNE buffer) at $37^{\circ} \mathrm{C}$ three times $10 \mathrm{~min}$ each; TNE buffer containing $20 \mu \mathrm{g} / \mathrm{ml}$ RNase A at $37^{\circ} \mathrm{C}$ for $45 \mathrm{~min}$; TNE buffer at $37^{\circ} \mathrm{C}$ for $15 \mathrm{~min} ; 50 \%$ formamide, $2 \times \mathrm{SSC}$ and $1 \mathrm{mM}$ DTT at $60^{\circ} \mathrm{C}$ for 30 $\min ; 2 \times \mathrm{SSC}$ at $37^{\circ} \mathrm{C}$ for $20 \mathrm{~min}$; and $0.1 \times \mathrm{SSC}$ at $37^{\circ} \mathrm{C}$ for $20 \mathrm{~min}$. After dehydration, slides were dipped into Kodak emulsion NTB-2 for $3 \mathrm{~d}$, and developed in Kodak D-19.

PCR analysis of APLP2 $m R N A$. Total RNA was isolated by homogenization of mouse olfactory epithelium and whole brain in $4 \mathrm{M}$ guanidine thiocyanate and centrifugation of the lysate over a $5.7 \mathrm{M}$ cesium chloride cushion (Chirgwin et al., 1979). Reverse-transcribed RNA was used in PCR to amplify alternatively spliced APLP2 mRNA. The primer pair SD2, 5'-CCGCTCGAGGAACAGCGAGCG-3' (encoding amino acids 567-570 of APLP2, and containing an XhoI site at its $5^{\prime}$ end) and antisense primer AsD2, 5'-CCGGAATTCATTGCTGCTCAAACTGAAATCC- $3^{\prime}$ (complementary to sequences encoding amino acids 675-681 of APLP2-751 and containing an EcoRI site at its $5^{\prime}$ end) was used to analyze the presence of alternatively spliced transcripts which encode a 12 amino acid peptide, DTQPELYHPMKK; primer pair SKPI, 5'GTGCTGCCCTCAGACAAAG-3' (encoding amino acids 202-207 of APLP2) and antisense primer AsD2 (above) was used to analyze alternatively spliced transcripts which encode the KPI domain and/or the 12 amino acid peptide (see above). In order to identify PCR products generated from the four different mRNA isoforms of APLP2, cloned cDNA corresponding to APLP2-694, APLP2-751, or APLP2-763 were used as templates in parallel PCR reactions. The PCR products were separated on $1.3 \%$ agarose or 3\% NuSieve GTG agarose (FMC Bioproducts, Rockland, $\mathrm{ME}$ ) and visualized by ethidium bromide staining.

Immunocytochemistry. C57/B16 mice (Jackson Laboratories, Bar Harbor, Maine) or adult Sprague-Dawley rats were administered lethal doses of the anesthetic Xylaket (25\% ketamine, $2.5 \%$ xylazine in $15 \%$ ethanol, $0.9 \%$ saline) and perfused intracardially with PBS, followed by $4 \%$ freshly depolymerized paraformaldehyde in $0.1 \mathrm{M}$ PBS. The olfactory epithelium was dissected following removal of craniofacial skeletal tissuc and fascia and postfixed in $4 \%$ paraformaldehyde in PBS for 2 hr. Olfactory bulbs were dissected and postfixed as above. After fixation, dissected tissue was equilibrated and cryoprotected in $10 \%$ sucrose in PBS at $4^{\circ} \mathrm{C}$, then transferred to plastic molds and embedded in OCT medium (Tissue Tek, Miles, Inc., Elkhart, IN) on dry ice. Tissue was stored at $-20^{\circ} \mathrm{C}$ until cryostat sections $(10 \mu \mathrm{m})$ were cut onto gelatinsubbed glass slides and stored at $-20^{\circ} \mathrm{C}$.

For immunocytochemical analysis, sections were first blocked for 1 $\mathrm{hr}$ in PBS containing 10\% normal goat serum, $1 \%$ bovine serum albumin and permeabilized in $0.1 \%$ Triton X-100 in PBS. Primary antibodies were incubated with sections overnight at $4^{\circ} \mathrm{C}$ in $4 \%$ normal goat serum. CT12 IgG was used at $6 \mu \mathrm{g} / \mathrm{ml}$, and control reactions were performed by preincubating an equivalent aliquot of antibody overnight 
at $4^{\circ} \mathrm{C}$ with $60 \mu \mathrm{g} / \mathrm{ml}$ of CT12 peptide. D2-I and D2-II antibodies were affinity purified on a GST-fusion protein matrix (sec above) and used at $0.5 \mu \mathrm{g} / \mathrm{ml}$. For control reactions, the appropriate dilution of antibody was preincubated overnight with $25 \mu \mathrm{g}$ of GST-fusion protein bound to matrix and used as indicated above. Primary antibodies were recognized and subsequently visualized using an avidin-biotin-peroxidase kit (Vector, Burlingame, CA) according to the manufacturer's instructions and visualized with diaminobenzidine. Sections were viewed and photographed using a Zeiss Axiophot microscope and camera and images were processed and compiled using an AGFA color scanner and image analysis system.

Laser scanning confocal microscopy. Forty micrometer thick paraformaldehyde-fixed brain sections were double immunolabeled using a combination of polyclonal anti-APLP2 specific antibody, D2-I (at $1: 500$ ), with monoclonal anti-synaptophysin (at 1:20) or monoclonal anti-MAP-2 antibodics (at 1:20) (anti-synaptophysin and anti-MAP-2 antibodies were from Boehringer-Mannheim Labs, Indianapolis, IN). Bound antibodies were subsequently reacted with a FITC-conjugated horse anti-mouse IgG (1:75) and biotinylated goat anti-rabbit IgG secondary antibodies $(1: 100)$, followed by avidin-Texas red $(1: 100)$ (Vector, Burlingame, CA). The double stained sections were transferred to SuperFrost plus slides (Fisher, Tustin, CA) and mounted under glass coverslips with anti-fading media containing $4 \% n$-propyl gallate (Sigma, St. Louis, MO). Sections were examined using the Bio-Rad MRC600 laser scanning microscope mounted on an Zeiss Axiovert $35 \mathrm{mi}$ croscope and optical Z-sections $0.5 \mu \mathrm{m}$ in thickness were collected arid stored as described (Masliah et al., 1993).

Preparation of brain extracts. Adult Sprague-Dawley rats were deeply anesthetized and perfused transcardially with PBS. The brain was then rcmoved and different regions were dissected quickly and frozen at $-70^{\circ} \mathrm{C}$. Soluble and membrane protein extracts were prepared as described (Blackstone et al., 1992). Briefly, tissues were homogenized with a Brinkmann Polytron in 10 volumes of ice-cold $10 \mathrm{~mm}$ Tris- $\mathrm{HCl}$ (pH 7.4) containing $10 \%$ (wt/vol) sucrose and protease inhibitors (20 $\mu \mathrm{g} / \mathrm{ml}$ each of leupeptin, pepstatin, antipain, and chymostatin, $0.2 \mathrm{U} / \mathrm{ml}$ aprotinin, $10 \mathrm{~mm}$ benzamidine, $0.1 \mathrm{mM}$ PMSF, $1 \mathrm{mM}$ EGTA, and $1 \mathrm{mM}$ EDTA). The homogenate was centrifuged at $1000 \times g$ for $10 \mathrm{~min}$ to remove nuclei and cell debris, and the resulting supernatant fraction was centrifuged at $114,000 \times g$ for $20 \mathrm{~min}$ at $4^{\circ} \mathrm{C}$. The supernatant fraction (S2) from the high speed centrifugation containing soluble proteins was saved. The pellet fraction (P2) containing membrane proteins was washed twice by resuspension in homogenization buffer (lacking sucrose), centrifuged at $114,000 \times g$ for $20 \mathrm{~min}$ and finally resuspended in homogenization buffer. Glycerol was added to both S2 and P2 fractions to a final concentration of $20 \%$ and the extracts were stored at $-70^{\circ} \mathrm{C}$.

Chondroitinase digestion. Ten microgram aliquots of the $\mathrm{S} 2$ fraction prepared from olfactory bulb and hippocampus were digested with 5 $\mathrm{mU}$ of protease-free chondroitinase ABC (Seikagaku America, Inc., Rockville, MD) in $100 \mathrm{mM}$ Tris- $\mathrm{HCl}(\mathrm{pH} 8.0)$ and $30 \mathrm{mM}$ sodium acetate for $1 \mathrm{hr}$ at $37^{\circ} \mathrm{C}$. As a positive control for chondroitinase digestions, we used serum-free conditioned medium prepared from a $\mathrm{CHO}$ cell line, B2, that constitutively expresses mouse APLP2-751 (Thinakaran and Sisodia, 1994) and which secretes soluble CS GAG-modified APLP2 derivatives.

\section{Results}

\section{Biochemical characterization of anti-APLP2 antibodies}

In an earlier report (Slunt et al., 1994), we noted that several widely utilized antibodies raised against APP are highly crossreactive with APLP2, a result due in large part to the significant sequence homology between the two proteins. In the present study, we report on the characterization of APLP2-specific antibodies and the use of these reagents in immunocytochemical and biochemical studies of the distribution of APLP2 in the rodent nervous system. To assess the specificity of antibodies D2-I (Thinakaran and Sisodia, 1994) and D2-II, raised against fulllength mouse APLP2-751 or CT12 antisera, generated against the C-terminal 12 amino acids of APLP2, we performed immunoblot analyses of lysates prepared from COS- 1 cells transiently transfected with expression plasmids encoding mouse APP-695, mouse APLP1, or mouse APLP2-751. To document that each of the transgene-derived polypeptides were expressed in transiently transfected cells, we immunoprecipitated each species from ${ }^{35} \mathrm{~S}$-methionine-labeled detergent lysates using an an-. tibody Ab369, raised against the entire cytoplasmic tail (residues 645-694) of APP-695 (Buxbaum et al., 1990). We anticipated that Ab369 would recognize APLP1 based on our earlier studies documenting that Ab369 recognizes APLP2 (Slunt et al., 1994). Ab369 immunoprecipitated low levels of endogenously expressed $\sim 110, \sim 115$, and $\sim 130 \mathrm{kDa}$ APP/APLP polypeptides from extracts of COS- 1 cells transfected with the expression plasmid which lacked a cDNA (Fig. $1 A$, lane 1). As expected, COS-1 cells transfected with plasmid pEF695 overexpressed $\sim 110 \mathrm{kDa}$ APP-695 (Fig. 1A, lane 2). Furthermore, cells transfected with plasmids pSVAPLP1 or pSVAPLP2 expressed $\sim 100$ $\mathrm{kDa}$ APLP1 or $\sim 120 \mathrm{kDa}$ APLP2 polypeptides, respectively (Fig. 1A, lanes 3 and 4 , respectively); the heterogeneous smear of polypeptides extending from $\sim 125 \mathrm{kDa}$ to $\sim 200 \mathrm{kDa}$ in lane 4 represents CS GAG-modified forms of APLP2-751 (see below, Thinakaran and Sisodia, 1994).

Antibody D2-I, raised against full-length mouse APLP2-751 detected low levels of endogenously synthesized $\sim 110$ and 115 $\mathrm{kDa}$ polypeptides in COS-1 cells (Fig. 1C, lane 1) and high levels of $\sim 115-200 \mathrm{kDa}$ forms of APLP2 from extracts of cells transfected with APLP2-751 cDNA (Fig. 1C, lane 4). Similarly, antibody D2-II recognized high levels of $\sim 115-200 \mathrm{kDa}$ forms of APLP2 in extracts of cells expressing APLP2-751 (Fig. 1C, lanc 8). Neither D2-I nor D2-II antibodies detected transiently expressed mouse APP-695 or APLP1 (Fig. 1C, lanes 2,3 and 6,7 , respectively). Antibody CT12, raised against the C-terminal 12 amino acids of APLP2, also detected low levels of endogenously synthesized $\sim 110$ and $115 \mathrm{kDa}$ polypeptides in COS-1 cells (Fig. 1C, lane 9) and an $\sim 115 \mathrm{kDa}$ form of APLP2 in extracts of cells overexpressing APLP2 (Fig. 1C, lane 12). Mureover, CT12 failed to detect either APP-695 or APLP1 (Fig. $1 C$, lanes 10 and 11 , respectively). The heterogeneity of the mature forms of APLP2 (Fig. 1C, lanes 4, 8) is the result of addition of variable-length CS GAG chains to APLP2 core proteins (Thinakaran and Sisodia, 1994). The apparent failure of CT12 antibody to detect the heterogeneous APLP2 species is due to the insensitivity of this reagent relative to the D2-I and D2-II antibodies. Thus, these results unambiguously document that antibodies D2-I, D2-II, and CT12 specifically recognize $\Lambda$ PLP2, but not its homologous proteins, APP and APLP1.

\section{Localization of APLP2 in cortical and hippocampal neurons}

Consistent with our earlier in situ hybridization analyses of APLP2 mRNA expression (Slunt et al., 1994), immunocytochemical mapping with antibodies D2-I, D2-II, and CT12 verified that APLP2 is expressed in neuronal populations in many regions of mouse brain, including ccrcbral cortex, hippocampus, and thalamus. To examine the subcellular distribution of APLP2 in neuronal populations in cortex and hippocampus, we doublestained sections with D2-I and synaptophysin, a marker for presynaptic boutons, or for D2-I and MAP-2, a dendritic cytoskeleton-associated marker. Sections were analyzed by laser scanning confocal microscopy. In the hippocampus, predominant APLP2 immunoreactivily (IR) was observed in apical dendrites (Fig. $2 b$ ), structures which were strongly stained with antibodies specific to the dendritic marker, MAP-2 (Fig. 2a,c). Parallel colocalization studies of APLP2 IR (Fig. 2e) and synaptophysin IR (Fig. $2 d$ ) again revealed prominent localization of APLP2 in apical dendrites, but some overlap in IR was evident in the neu- 
A

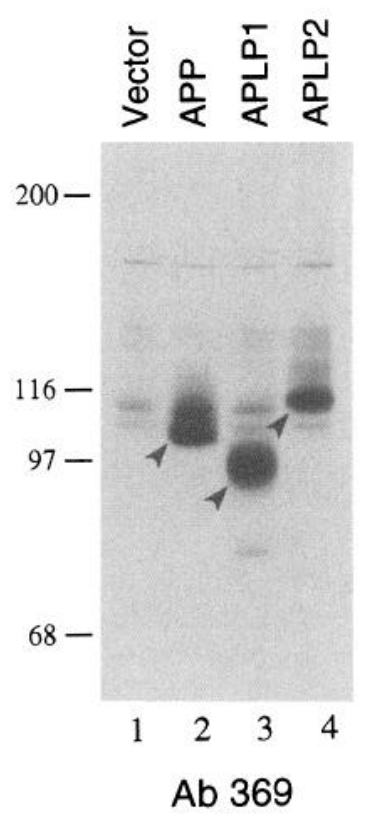

B

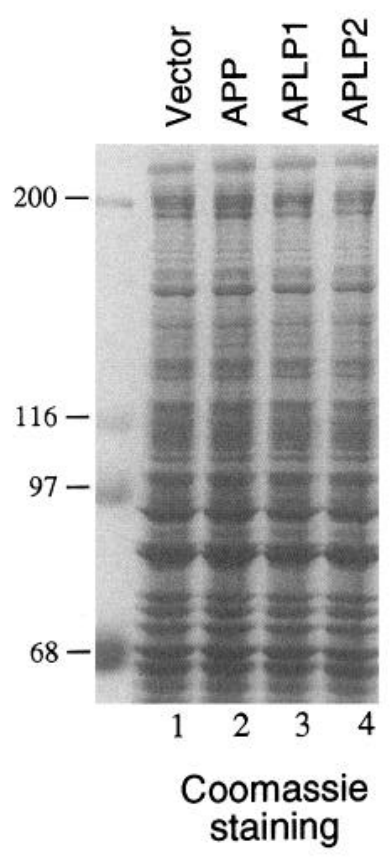

$\mathbf{C}$

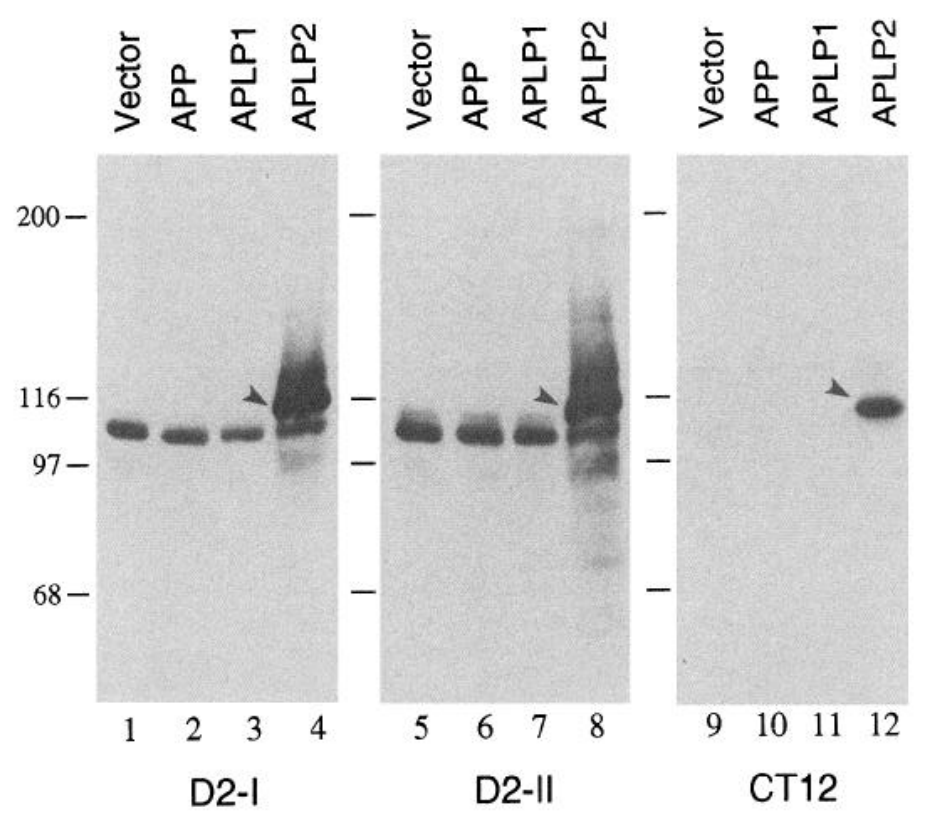

Figure 1. Biochemical characterization of APLP2 antibodies. COS-1 cells were transfected with a plasmid vector or plasmids encoding mouse APP-695, mouse APLP1 or mouse APLP2-751. Detergent lysates of cells were used for immunoprecipitation and Western blot analysis. A, Expression of APP and the homologues in COS-1 cells. Lanes 1-4 represent Ab369 immunoprecipitates prepared from COS-1 cells transfected with plasmid vector or cells transiently expressing mouse APP, APLP1, or APLP2, respectively. Exogenous APP, APLP1 and APLP2 polypeptides are indicated by arrowheads. B, Coomassie blue staining of lysates used for Western blotting experiments shown in $C$. $C$, Western blot analysis of APLP2 antibody specificity. Lysates of COS-1 cells transfected with plasmid vector (lanes 1,5, and 9) or plasmids encoding APP-695 (lanes 2,6, and 10), APLP1 (lanes 3,7, and 11), and APLP2-751 (lanes 4,8, and 12) were probed with APLP2 antibodies D2-I (lanes 1-4), D2-II (lanes 5-8), and CT12 (lanes 9--12). Exogenous APLP2-751 is marked by arrowheads.

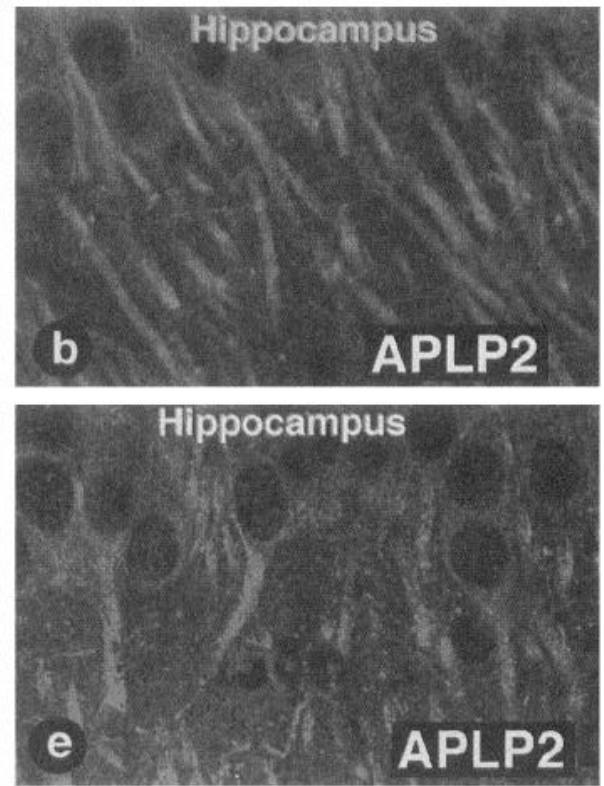
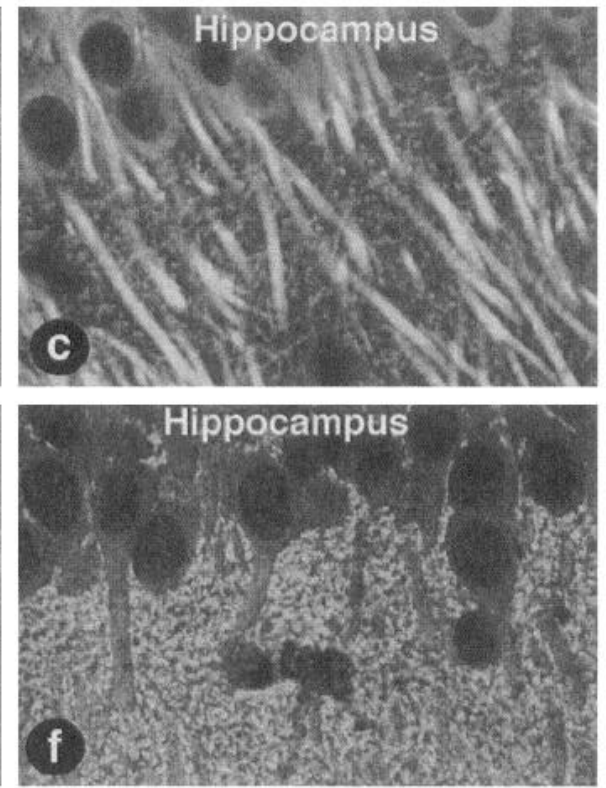

Figure 2. Laser scanning confocal images of APLP2 IR in mouse hippocampus. $a$, Anti-MAP-2 antibody staining of mouse hippocampus. $b$, Costaining of the section shown in $A$ with antibody D2-I. $c$, Overlap of the images presented in $a$ and $b$. Overlap of the two markers confirms the predominant dendritic localization of APLP2. $d$, Anti-synaptophysin antibody staining of mouse hippocampus. $e$, Costaining of the section shown in $d$ with antibody D2-I. $f$, Overlap of the images shown in $d$ and $e$. 

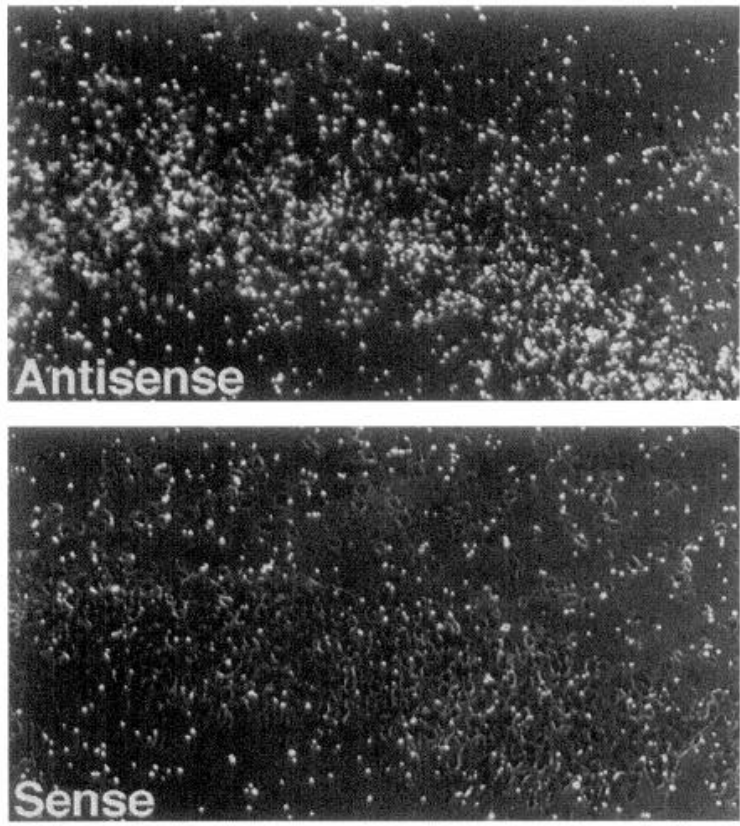

Figure 3. In situ hybridization of APLP2 mRNA in mouse olfactory epithelium. Shown are dark-field photomicrographs of olfactory epithelium (external surface facing towards bottom) hybridized with APLP2 antisense and sense riboprobes.

ropil, as well (Fig. $2 f$ ). Similarly, in cortex, we observed an essentially identical colocalization pattern with APLP2 and MAP-2 antibodies in dendrites, with modest overlap in staining using APLP2 and synaptophysin antibodies in the neuropil (data not shown). As part of our effort to map the distributions of APLP2 in brain, we noted an interesting distribution of this molecule in the rodent olfactory system. Hence, we have focused our attention on the distribution of APLP2 mRNA and proteins in cells within this circuit.

\section{Expression of APLP2 $\mathrm{mRNA}$ in olfactory epithelium}

To examine the cellular expression of APLP2 mRNA in the olfactory epithelium, we used in situ hybridization analysis. We generated ${ }^{33} \mathrm{P}$-labeled riboprobes complementary to the sequences that encode a 110-amino acid stretch that immediately precedes the transmembrane domain of APLP2; this sequence of APLP2 is highly divergent from an analogous region of APP (Slunt et al., 1994). In Figure 3, we demonstrate that mRNAs encoding APLP2 are abundantly expressed throughout the re- gion of the olfactory epithelium that contains sensory neurons and sustentacular cells.

On the basis of earlier studies which documented that the primary APLP2 transcript undergoes alternate splicing (Sprecher et al., 1993; Wasco et al., 1993; Sandbrink et al., 1994; Slunt et al., 1994), we carried out RT-PCR analysis of mRNA prepared from olfactory epithelium. The alternatively spliced APLP2 transcripts encode APLP2 polypeptides of $694,706,751$, or 763 amino acids (Fig. 4). The 751 and 763 isoforms contain a domain homologous to the Kunitz protease inhibitors, while the 694 and 706 forms lack this region. Moreover, the 706 and 763 forms contain an additional 12 amino acid sequence encoded by an alternatively spliced exon. We recently documented that APLP2-751 undergoes modification by the addition of CS GAG at a single site, serine-614 (Thinakaran and Sisodia, 1994). The amino acid sequence near the CS GAG attachment site is ENEGSGMAEQ (residues 610-619 of the APLP2-751 isoform). Notably, the additional 12 amino acid sequence in the APLP2706 and APLP2-763 isoforms is inserted immediately upstream of the CS attachment site. The sequence of the insert and residues flanking the CS GAG attachment site is ENEDTQPELYHPMKKGSGMAEQ. Indeed, we have recently demonstrated that the APLP2-763 isoform fails to be modified by CS GAG (Thinakaran et al., 1995) suggesting that the insert disrupts the optimal recognition sequence for CS GAG addition. For example, in transiently transfected COS-1 cells, APLP2-751 is synthesized as an $\sim 120 \mathrm{kDa}$ polypeptide, and matures into heterogeneous CS GAG-modified polypeptides of $\sim 130-200 \mathrm{kDa}$ (Fig. 5A, lane 1). In contrast, APLP2-763 is synthesized as a $\sim 120 \mathrm{kDa}$ molecule, and matures into a homogeneous polypeptide of $\sim 130 \mathrm{kDa}$ (Fig. $5 A$, lane 2). Furthermore, immunoprecipitation of soluble APLP2-derivatives from conditioned media also revealed that APLP2-751 is secreted as heterogeneous population of polypeptides of $\sim 100-150 \mathrm{kDa}$, while APLP2-763 is secreted as a $\sim 100 \mathrm{kDa}$ polypeptide (Fig. 5A, lanes 3 and 4). These results demonstrate that unlike APLP2-751, the APLP2763 isoform fails to undergo modification by CS GAG. Thus, we conclude that only two of the alternatively spliced isoforms of APLP2, APLP2-694, and APLP2-751 are substrates for modification by the addition of CS GAG chains.

In order to determine whether APLP2 mRNA expressed in olfactory epithelium contains alternatively spliced sequence encoding the 12 amino acid peptide, we performed RT-PCR analysis with primers that flank the sequence and we expected two products. We performed a parallel analysis of RNA isolated from mouse brain. Equal amounts of RNA from each tissue were

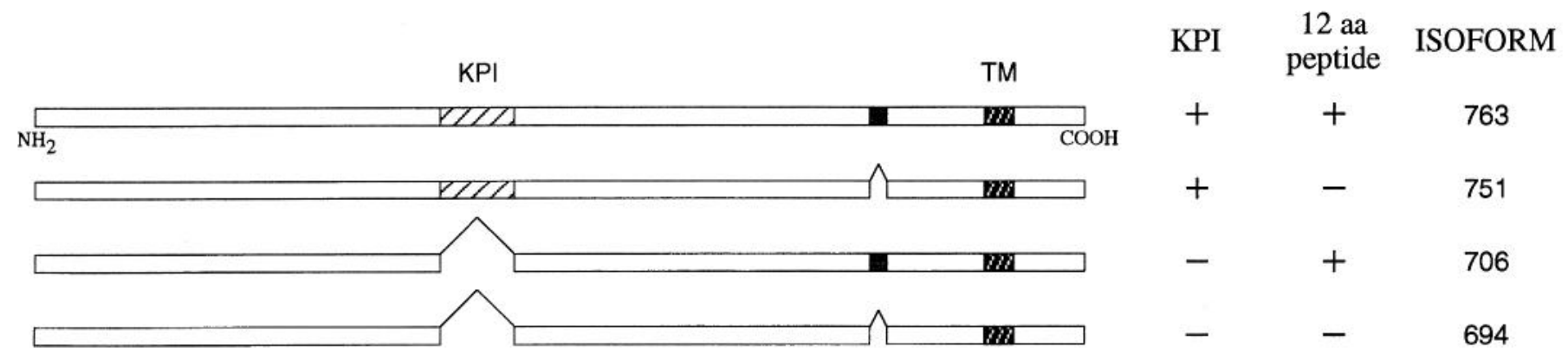

Figure 4. Structure of APLP2 isoforms encoded by alternatively spliced transcripts. KPI, Kunitz protease inhibitor domain; stippled box, 12 amino acid peptide; $T M$, transmembrane domain. 


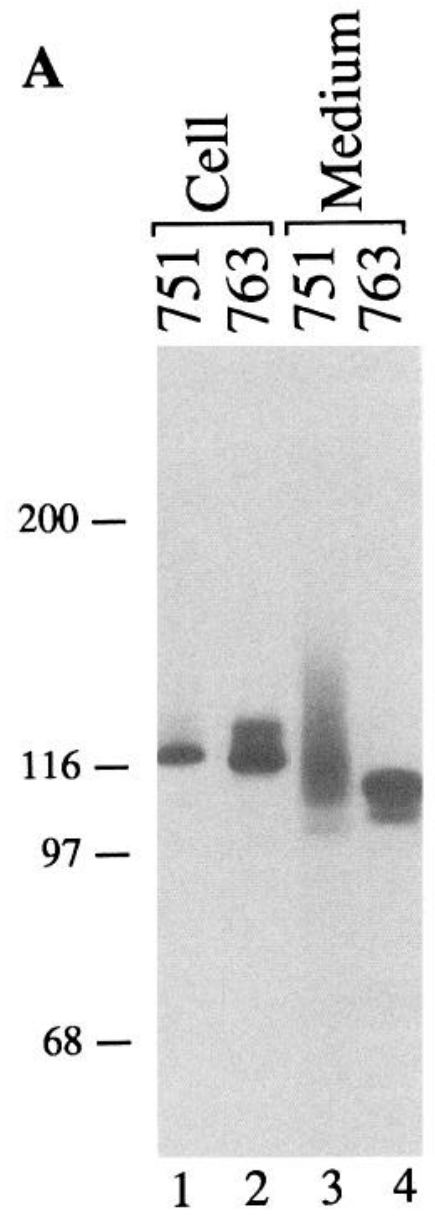

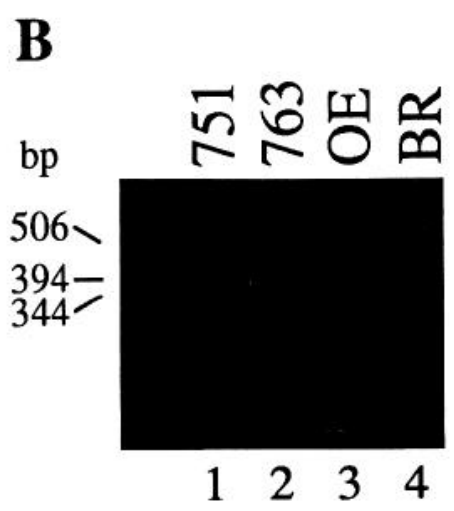

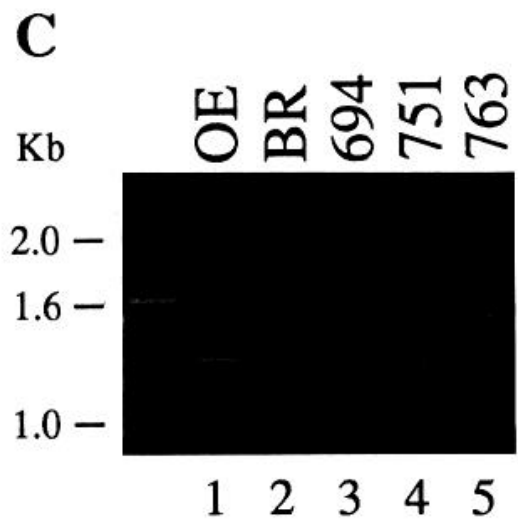

Figure 5. Posttranslational processing of APLP2 isoforms and APLP2 mRNA expression in mouse brain and olfactory epithelium. A, Maturation of APLP2 isoforms in transfected COS-1 cells. Lanes 1 and 2 represent exogenous Myc-tagged APLP2 immunopretcipitated using antibody Myc-I, from COS-1 cells transfected with cDNA encoding APLP2-751 or APLP2-763, respectively. Lanes 3 and 4 represent soluble derivatives of APLP2-751 or APLP2-763, respectively, immunoprecipitated from conditioned medium using antibody D2I. $B$, Ethidium bromide stained gel of PCR products generated using primers that flank the sequences encoding the 12 amino acid peptide. Lanes $I$ and 2 represent PCR products derived from cDNA which encode APLP2-751 and APLP2-763, respectively. Lanes 3 and 4 represent PCR products generated from reverse-transcribed RNA isolated from olfactory epithelium $(O E)$ and brain $(B R)$, respectively. $C$, Ethidium bromide stained gel of PCR products generated using a sense primer upstream of the KPI domain (SKPI) and antisense primer $(A s D 2)$ downstream of the sequences encoding the 12 amino acid peptide. Lanes 1 and 2 represent RT-PCR products generated from olfactory epithelium $(O E)$ and brain $(B R)$, respectively. Lanes 3-5 represent PCR products derived from cDNA which encode APLP2-694, APLP2-751, or APLP2763 , respectively. reverse transcribed, and the resulting cDNA subject to PCR for an identical number of cycles. We demonstrate that In brain, the vast majority of PCR product is the longer form and thus contains sequences which encode the 12 amino acid peptide (Fig. $5 B$, lane 4$)$. These results are essentially indistinguishable from quantitative RT-PCR studies of mRNA from rat cortex, hippocampus, and cerebellum in which transcripts encoding the 12 amino acid peptide represented $87 \%, 92 \%$, and $95 \%$, respectively, of total APLP2 mRNA in these tissues (Sandbrink et al., 1994). On the other hand, the shorter PCR product is the predominant species in olfactory epithelium and hence lacks sequences that encode the peptide (Fig. 5B, lane 3). To distinguish between APLP2 mRNA that contained both, or either the 12 amino acid peptide and KPI sequences, we performed RT-PCR analysis with a sense primer upstream of the KPI domain and an antisense primer downstream of the insertion site. PCR analysis revealed that the vast majority of APLP2 mRNA expressed in olfactory epithelium does not contain the sequences encoding the KPI domain (Fig. $5 C$, lane 1), whereas, the majority of the APLP2 mRNA expressed in brain contains this sequence (Fig. $5 C$, lane 2). Thus, we conclude that the CS GAG modified isoforms, APLP2-694 and APLP2-751, are the preponderant APLP2 isoforms expressed in olfactory epithelium.

\section{Immunocytochemical localization of APLP2 in the rodent olfactory system}

We performed immunocytochemical analysis of the distribution of APLP2 in the olfactory system of mouse and rat using the APLP2-specific antibodies described above. For immunocyto- chemical analysis of the mouse olfactory system, we affinity purified D2-I and D2-II antibodies on a bacterially expressed fusion protein (GST $\triangle$ APLP2) that contained a 120 amino acid region of APLP2-751 which occurs immediately N-terminal to the transmembrane domain. The affinity purified antibodies detect both full-length and soluble (C-terminal truncated) APLP2 derivatives (G. Thinakaran and S. Sisodia, unpublished observations), similar to those detected with unpurified APLP2 antisera (Thinakaran and Sisodia, 1994). Immunocytochemical analysis of the mouse olfactory epithelium with affinity purified D2-I antibody revealed remarkable APLP2 IR in the sensory axons of olfactory receptor cells that are arranged in parallel fiber bundles and destined for the olfactory bulb (Fig. 6A); an essentially indistinguishable pattern of IR was obtained with antibody D2II (Fig. 6C). We demonstrated that the D2-I labeled structures are axon bundles by demonstrating cclocalization with the neuron-specific Class III $\beta$-tubulin monoclonal antibody, TuJ1 (Lee et al., 1990) (data not shown). Moreover, immunostaining patterns obtained with D2-I and D2-II antibodies were fully competable by prior incubation of the antibodies with the GST $\Delta$ APLP2 fusion protein (Fig. $6 B, D$ ). Finally, we stained parallel sections with CT12 antisera, raised against the C-terminal 12 amino acids of APLP2 and which only recognize full-length APLP2 and its membrane-bound metabolites. As was observed with the D2-I and D2-II antibodies, CT12 antiserum strongly stained the sensory axon bundles (Fig. $6 E$ ) in the olfactory epithelium. Immunostaining was competable by prior incubation of the CT12 antiserum with CT12 peptide (Fig. $6 F$ ). Given the strong staining in the sensory axon bundles in the olfactory ep- 



Figure 6. APLP2 IR in mouse olfactory epithelium; $10 \mu \mathrm{m}$ sections of olfactory neuroepithelium were examined immunohistochemically for APLP2 IR using affinity purified antibodies D2-I $(A)$, D2-II $(C)$, and CT12 antisera $(E)$. In all cases, only light APLP2 IR was detected in the olfactory receptor neurons $(O R N)$. However, APLP2 IR was highly enriched in afferent axons $(A x)$ projecting to the olfactory bulb. APLP2 IR was abolished by preincubation of D2-I and D2-II antibodies with GST $\triangle$ APLP2 fusion protein $(B$ and $D)$ and CT12 antisera with immunizing peptide $(F)$.

ithelium, we anticipated that APLP2 would also be localized to the terminal fields of the sensory afferents in the olfactory bulb. Using antibody D2-I, we show remarkable APLP2 IR in the glomeruli of the olfactory bulb (Fig. 7A). In addition, fine APLP2 IR is seen in dendrites and cell bodies of mitral, tufted and granule cells, along with scattered APLP2 IR throughout the neuropil of the external plexiform layer. Indeed, the glomeruli were also strongly stained with D2-II antibody and CT12 antiserum (Fig. 7, $C$ and $E$, respectively). Moreover, staining in the olfactory bulb by all three antibodies was competable with re- 



Figure 7. APLP2 IR in mouse olfactory bulb; $10 \mu \mathrm{m}$ sections of olfactory bulb were examined immunohistochemically for APLP2 IR using affinity purified antibodies D2-I $(A)$, D2-II $(C)$, and CT12 antisera $(E)$. APLP2 IR was detected primarily in glomeruli $(G I)$ and mitral cells of the olfactory bulb, where axons from the neuroepithelium terminate and synapse. APLP2 IR was abolished by preincubation of D2 antibodies with GST $\triangle$ APLP2 fusion protein $(B$ and $D)$ and CT12 antisera with immunizing peptide $(F)$

spective antigens (Fig. $7 B, D, F$, respectively). Taken together with our observation that antibodies against nonoverlapping epitopes of APLP2 recognize an essentially indistinguishable set of structures in the olfactory system (i.e., in sensory axon bundles and glomeruli), the competition studies provide compelling ev- idence that APLP2 and/or its metabolites are being specifically recognized by each of the antibodies in situ.

To demonstrate that the pattern of immunostaining in mice detected with the APLP2 antibodies was conserved in another rodent species, we immunostained sections of rat olfactory ep- 



Figure 8. APLP2 IR in rat olfactory epithelium and bulb. A, A cross-section of rat olfactory epithelium $(O E)$ and olfactory bulb $(O B u)$ was examined for APLP2 expression using affinity purified D2-I antibodies. Axons bundles $(A x)$ are clearly seen underlying the olfactory receptor neuron layer $(O R N)$ and bundles of axons (arrow) are seen projecting through the cribiform plate $(C P)$ into the glomerular layer $(G I)$ of the olfactory bulb. $B$, Higher power view of APLP2 IR in axons projecting through the cribiform plate into the glomerular layer. $C$, Higher power view of APLP2 IR in the glomerular layer.

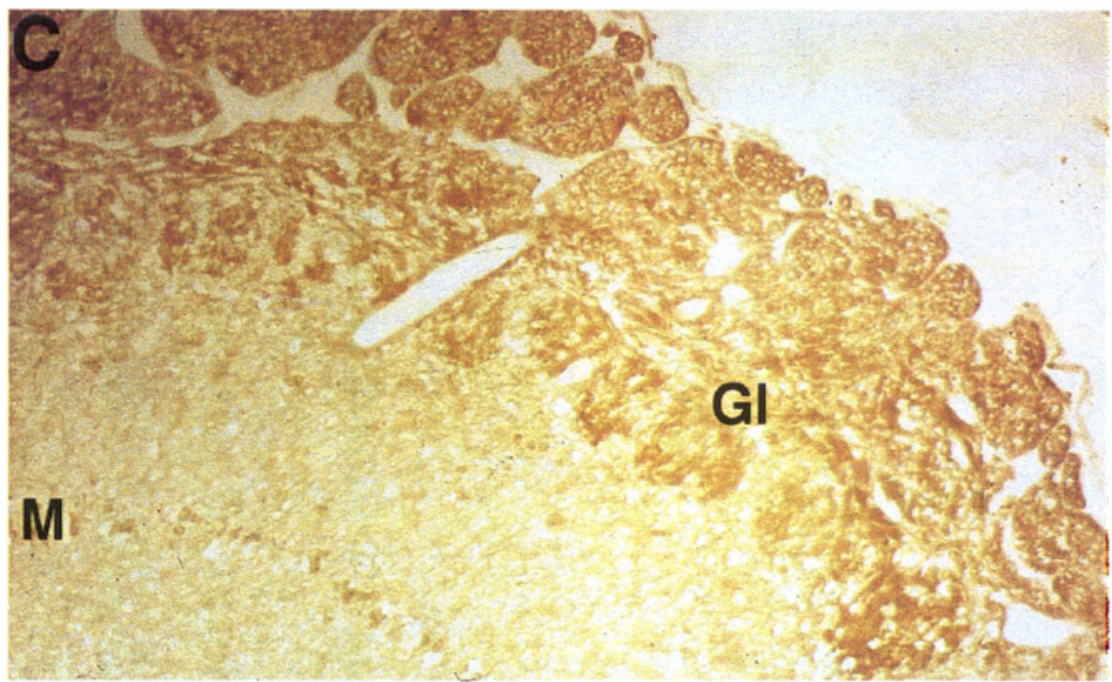

ithelium and olfactory bulb with affinity purified antibody D2I. A low power view of a cross-section through the olfactory epithelium and bulb shows strong staining of the sensory axons and glomeruli (Fig. 8A). A higher power view illuminates coursing of D2-I immunoreactive sensory axon bundles from the ep- ithelium through the cribiform plate towards the olfactory bulb (Fig. $8 B$ ). Finally, a higher power view of the glomeruli shows strong D2-1 IR in this structure (Fig. $8 C$ ).

In order to define the subcellular localization of APLP2 in the glomeruli, we double-stained sections of the olfactory bulb with 

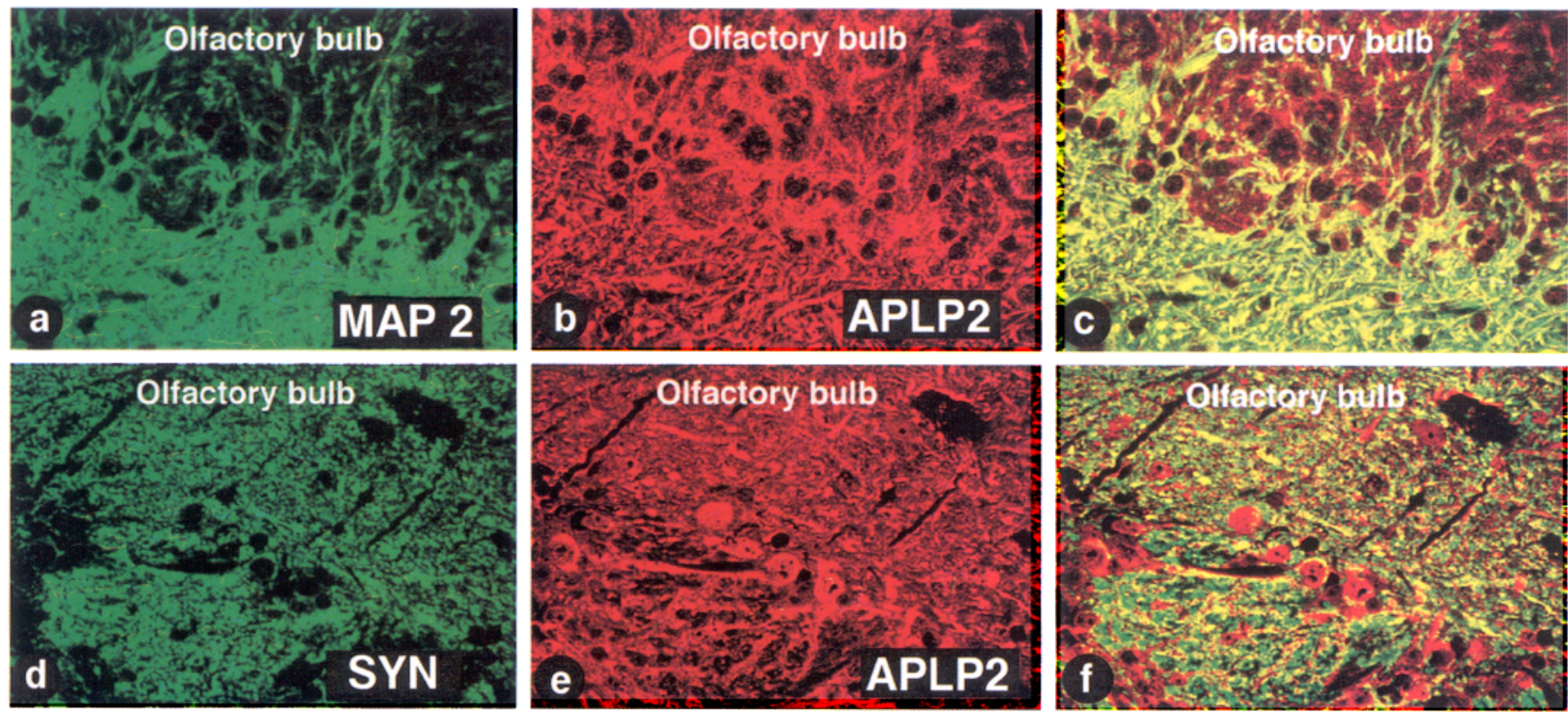

Figure 9. Laser scanning confocal images of APLP2 IR in mouse olfactory bulb. $a$, Anti-MAP-2 antibody staining of mouse olfactory bulb (green). MAP-2 staining is only light in glomeruli but is abundant in the outer plexiform layer. $b$, Costaining of the section shown in $A$ with antibody D2-I (red). D2-1 stains both the outer plexiform layers and glomeruli. c, Overlap of the images presented in $a$ and $b$. Yellow signifies overlap of the two markers. $d$, Anti-synaptophysin antibody staining of mouse olfactory bulb (green). $e$, Costaining of the section shown in $D$ with D2-I antibodies (red). $f$, Overlap of the images shown in $d$ and $e$. Yellow signifies overlap of the two markers; considerable staining of both the glomeruli and outer plexiform layer is apparent confirming that APLP2 is expressed in pre- and postsynaptic structures in the glomeruli.

D2-I and synaptophysin, or for D2-I and MAP-2, and analyzed optical sections by laser scanning confocal microscopy. As expected, synaptophysin IR was present both in the terminal fields of the olfactory sensory afferents within the glomeruli and the incoming fiber tracts (Fig. 9d). Costaining with the APLP2-specific antibody, D2-I, revealed conspicuous colocalization in structures stained with synaptophysin antibodies (Fig. $9 e, f$ ). On the other hand, MAP-2 antibody stained structures contained primarily in the external plexiform layer with negligible staining in the glomeruli (Fig. 9a). Similar to our observations in cortex and hippocampus, APLP2 IR strongly colocalized with MAP-2 immunoreactive structures in the external plexiform layer (Fig. 9c). Nevertheless, it is clear that APLP2 IR extended into the glomeruli, a region which was essentially devoid of MAP-2 IR (Fig. 9b,c).

\section{Characterization of APLP2 proteoglycan in olfactory bulb}

Analysis of APLP2 mRNA in the olfactory epithelium (Fig. $5 B, C$ ) strongly suggested that the encoded isoforms would be substrates for CS GAG addition. To assess the level of CS GAG modification of APLP2 in the olfactory system, we used D2-II antiserum in Western blot analysis of membrane-bound and soluble extracts prepared from olfactory bulb, a region which is enriched in APLP2 IR (see above). The D2-II antibody is specific for APLP2 (see Fig. 1). Immunoblot analysis of membrane fractions from whole brain, cortex, hippocampus, cerebellum, and spinal cord (Fig. 10A, lanes 1, 3-6, respectively) revealed the presence of discrete APLP2-related species of $\sim 95 \mathrm{kDa}$, $\sim 100 \mathrm{kDa}$, and $\sim 115 \mathrm{kDa}$. On the other hand, D2-II recognized the $\sim 95 \mathrm{kDa}, \sim 100 \mathrm{kDa}$, and $\sim 115 \mathrm{kDa}$ species and a heterogeneous pattern of polypeptides with apparent molecular weight of $\sim 120-160 \mathrm{kDa}$ range in the olfactory bulb (Fig. 10A, lane 2 ). We suggest that the membrane-bound APLP2 forms in the olfactory bulb sample that migrate between the $\sim 120-160 \mathrm{kDa}$ (Fig. 10A, lane 2) represent accumulated CS GAG-modified species synthesized by olfactory receptor neurons and transported to the olfactory bulb. Moreover, our results are fully consistent with the earlier RT-PCR analysis in which we demonstrate that the vast majority of APLP2 mRNA in the olfactory epithelium encodes isoforms postulated to undergo CS GAG modification while brain primarily expresses APLP2 mRNA encoding the CS GAG inhibitory 12 amino acid peptide (see Fig. $5 B, C$ ). To confirm that accumulated APLP2 in the olfactory bulb was indeed modified by CS GAG, we treated the soluble fraction (S2) with chondroitinase $\mathrm{ABC}$ and subject the resulting preparations to immunoblot analysis with antibody D2-II. Soluble APLP2 derivatives in the S2 fraction from olfactory bulb migrates as a doublet of $\sim 85 \mathrm{kDa}$ and $\sim 105 \mathrm{kDa}$ and a heterogeneous species between $\sim 90-115 \mathrm{kDa}$ (Fig. 10B, lane 1). Chondroitinase ABC treatment of the S2 fraction converted the heterogeneous population of molecules to fairly discrete band that overlaps the $\sim 85$ $\mathrm{kDa}$ species with little change in the levels of the $\sim 105 \mathrm{kDa}$ species (Fig. 10B, lane 2). Thus, we argue that the heterogeneity of the $\sim 90-115 \mathrm{kDa}$ APLP2-related molecules in the S2 fraction is the result of CS GAG modification of a C-terminally truncated APLP2 core protein of $\sim 85 \mathrm{kDa}$. In contrast, the APLP2 forms in the S2 fraction from hippocampus appear as $\sim 85 \mathrm{kDa}$ and $\sim 105 \mathrm{kDa}$ species (Fig. 10B, lane 3) which, as expected, are insensitive to digestion with chondroitinase $\mathrm{ABC}$ (Fig. 10B, lane 4). Finally, as a control for chondroitinase digestions, we prepared conditioned medium from $\mathrm{CHO}$ cells that constitutively express APLP2-751. As we previously documented (Thinakaran and Sisodia, 1994), soluble APLP2-751 derivatives secreted by $\mathrm{CHO}$ cells migrate as a smear between $\sim 120-150 \mathrm{kDa}$ (Fig. $10 B$, lane 5 ) and these forms are fully sensitive to chondroitinase 
Figure 10. Expression of CS GAGmodified APLP2 in the olfactory system. $A$, The P2 fraction $(10 \mu \mathrm{g}$ per lane) from whole brain, olfactory bulb, cortex, hippocampus, cerebellum, and spinal cord were fractionated by SDSPAGE and subject to immunoblotting with APLP2-specific antibody, D2-II. Arrowhead indicates the APLP2 proteoglycan expressed in the olfactory bulb. $B$, The $S 2$ fraction $(10 \mu \mathrm{g})$ prepared from olfactory bulb and hippocampus, or an aliquot of conditioned medium prepared from $\mathrm{CHO}$ cells stably expressing mouse APLP2-751 were incubated at $37^{\circ} \mathrm{C}$ in the presence (+) or absence $(-)$ of chondroitinase $\mathrm{ABC}$. After digestion, the samples were fractionated by SDS-PAGE and immunoblotted using APLP2 antibody, D2-II. The position of the chondroitinase-sensitive $\sim 90-120 \mathrm{kDa}$ APLP2 species are marked by a bracket. Note that following chondroitinase digestion of soluble APLP2 forms from olfactory bulb, a marked increase in the amount of $\sim 85 \mathrm{kDa}$ APLP2 polypeptide (marked by an arrowhead) is observed with little change in the $\sim 105 \mathrm{kDa}$ APLP2 polypeptide (marked by an asterisks).
$\mathbf{A}$

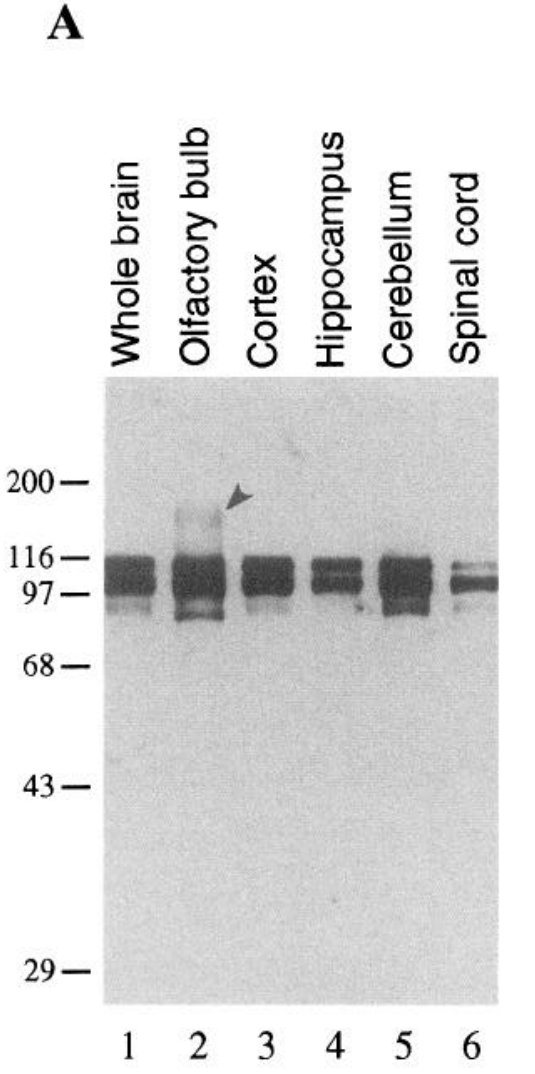

digestion, resulting in the production of a discrete species of $\sim 105 \mathrm{kDa}$ (Fig. 10B, lane 6).

\section{Discussion}

APP, the precursor of the A $\beta$ peptide, is a member of a family of closely related transmembrane glycoproteins that includes APLP1 and APLP2 (Wasco et al., 1992, 1993; Sprecher et al., 1993; Slunt et al., 1994). At present, APLP2 is the best characterized member of the APLPs. APLP2 mRNAs are expressed in most, if not all, neuronal populations in the CNS and at high levels in peripheral tissues (Wasco et al., 1993; Slunt et al., 1994). However, it is likely that the distribution of APLP2 in the CNS may show significant differences as compared to the mRNA expression patterns observed using in situ hybridization, particularly since APLP2, like APP (Koo et al., 1990; Sisodia et al., 1993), is transported in axons by the rapid anterograde component (G. Thinakaran and S. Sisodia, unpublished observations). Furthermore, it is conceivable that differences in proteolytic processing and/or secretion of APLP2 between cell types may lead to differential accumulation of the precursor isoforms and its derivatives. Immunocytochemical methods have been used to study the distribution of APP in CNS (Card et al., 1988; Shivers et al., 1988; Kawarabayashi et al., 1991; Martin et al., 1991; Imaizumi et al., 1993; Okuda et al., 1994; Ouimet et al., 1994; Trapp and Hauer, 1994) but because antibodies raised against independent epitopes of APP cross-react with APLP2 (Slunt et al., 1994), it is quite likely that the distributions of APP IR described in a variety of reports, including our own (Martin et al., 1991) reflect IR to APP, APLP2, and perhaps APLP1, as well. To define the distribution of APLP2 in the CNS, we generated a series of antibodies against nonoverlapping epitopes of mouse APLP2. Western blot analyses of lysates pre-

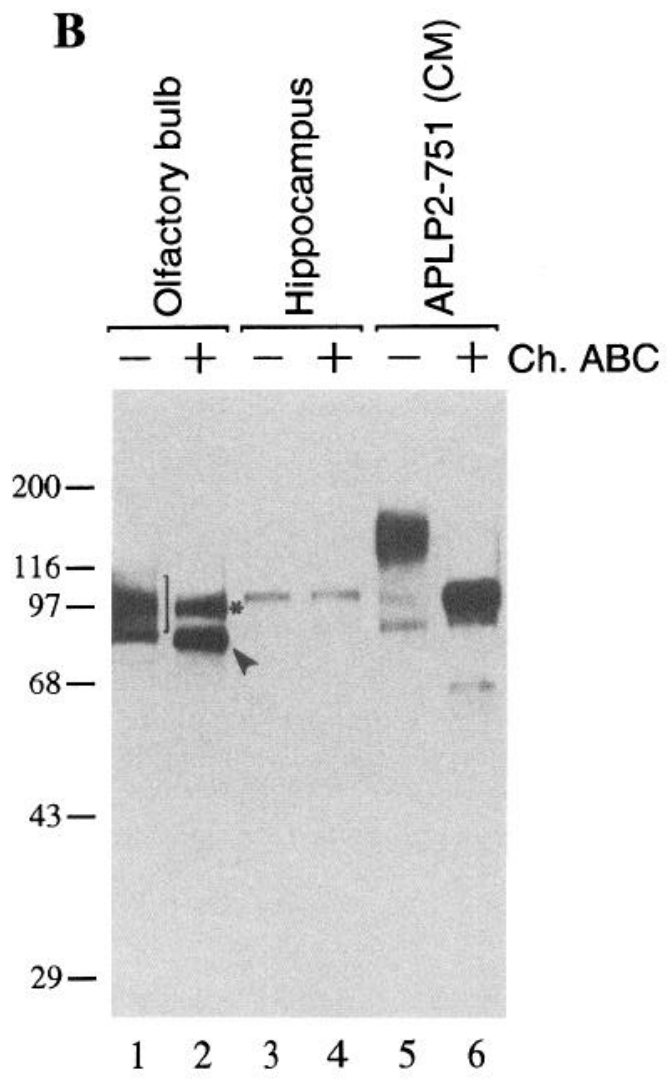

pared from COS-1 cells transiently transfected with cDNA encoding each of the known members of the APP family of proteins revealed that the APLP2 antibodies D2-I and D2-II and CT12 specifically recognize APLP2.

Previous in situ hybridization studies have shown that APLP2 is ubiquitously expressed in CNS. Indeed, our present immunocytochemical investigations confirm the in situ results, and in addition revealed that the preponderant subcellular localization of APLP2 in neurons of the cortex and hippocampus is in postsynaptic elements. Most provocative is our finding that APLP2, synthesized in sensory neurons of the olfactory epithelium, is enriched in sensory axons and sensory axon terminals in the glomeruli. In the olfactory bulb, colocalization studies of APLP2 with markers of synaptic (synaptophysin) or dendritic (MAP-2) structures reveal that APLP2 is present in presynaptic sites in the glomeruli as well as in postsynaptic elements in the outer plexiform layer.

Although speculative, we suggest that the unique distributions of APLP2 to sensory afferents and terminals may be linked to its generalized role in process formation or pathfinding, and connectivity. Olfactory sensory neurons are the only neuronal population in the adult mammalian CNS which are continuously renewed from a population of mitotic precursors, with replacement of neurons in the olfactory epithelium occurring every 4 6 weeks (Graziadei and Monti Graziadei, 1979). Hence, axonal outgrowth from newly born sensory neurons towards the olfactory bulb is a process that requires molecular clues involved in guidance, adhesion, and synaptogenesis. We recently demonstrated that APLP2 is a substrate for modification by the addition of CS GAG chains (Thinakaran and Sisodia, 1994). Alternatively-spliced mRNA encoding isoforms of APLP2 (APLP2-706 and APLP2-763) that do not undergo modification by CS GAG (Thi- 
nakaran et al., 1995) are the predominantly expressed in cortex, hippocampus, and cerebellum (Sandbrink et al., 1994), an observation we have now confirmed by biochemical analysis with our newly generated antibodies. However, the APLP2 isoforms which undergo CS GAG modification (APLP2-694 and APLP2751) are selectively expressed in olfactory epithelium. Although CS proteoglycans expressed by non-neuronal cells along pathways of axon outgrowth in developing retina (Brittis et al., 1992) and cerebellum (Friedlander et al., 1994) have been shown to repel axons, little is known regarding the role(s) of CS proteoglycans expressed intrinsically by neurons. Some studies, however have implicated a role for CS proteoglycans expressed on surfaces of neurons during development; in cerebellum, a CS proteoglycan of $\sim 250 \mathrm{kDa}$ core protein (6B4 proteoglycan) is expressed in Purkinje cells, Golgi cells, deep cerebellar neurons, and brainstem nuclei and enriched in the mossy fibers during the outgrowth and maturation phases (Maeda et al., 1992). We suggest that CS-modified APLP2 may play similar roles in axonal growth and synaptic maturation in the olfactory system.

\section{References}

Bourdon MA, Krusius T, Campbell S, Schwartz NB, Ruoslahti E (1987) Identification and synthesis of a recognition signal for the attachment of glycosaminoglycans to proteins. Proc Natl Acad Sci USA 84: 3194-3198.

Brittis PA, Canning DR, Silver J (1992) Chondroitin sulfate as a regulator of neuronal patterning in the retina. Science 255:733-736.

Buxbaum JD, Gandy SE, Cicchetti P, Ehrlich ME, Czernik AJ, Fracasso RP, Ramabhadran TV, Unterbeck AJ, Greengard P (1990) Processing of Alzheimer $\beta / A 4$ amyloid precursor protein: modulation by agents that regulate protein phosphorylation. Proc Natl Acad Sci USA 87: 6003-6006.

Card JP, Meade RP, Davis LG (1988) Immunocytochemical localization of the precursor protein for $\beta$-amyloid in the rat central nervous system. Neuron 1:835-846.

Chen C, Okayama H (1987) High-efficiency transformation of mammalian cells by plasmid DNA. Mol Cell Biol 7:2745-2752.

Chirgwin JM, Przybyla AE, MacDonald RJ, Rutter WJ (1979) Isolation of biologically active ribonucleic acid from sources enriched in ribonuclease. Biochemistry 18:5294-5299.

Friedlander DR, Milev P, Karthikeyan L, Margolis RK, Margolis RU, Grumet $M$ (1994) The neuronal chondroitin sulfate proteoglycan neurocan binds to the neural cell adhesion molecules $\mathrm{Ng}$ CAM/L1/NILE and N-CAM, and inhibits neuronal adhesion and neurite outgrowth. J Cell Biol 125:669-680.

Glenner GG, Wong CW (1984) Alzheimer's disease: initial report of the purification and characterization of a novel cerebrovascular amyloid protein. Biochem Biophys Res Commun 120:885-890.

Golde TE, Estus S, Usiak M, Younkin LH, Younkin SG (1990) Expression of $\beta$ amyloid protein precursor mRNAs: recognition of a novel alternatively spliced form and quantitation in Alzheimer's disease using PCR. Neuron 4:253-267.

Graziadei PPC, Monti Graziadei GA (1979) Neurogenesis and neuron regeneration in the olfactory system of mammals. I. Morphological aspects of differentation and structural organization of the olfactory sensory neurons. J Neurocytol 8:1-18.

Imaizumi K, Iwata H, Yoshida S, Sun G, Okumura N, Shiosaka S (1993) Coexistence of amyloid $\beta$-protein precursor and basic fibroblast growth factor in single cells of the rat parietal cortex, hippocampus and basal magnocellular nucleus. J Chem Neuroanat 6:159165.

Kang J, Lemaire H-G, Unterbeck A, Salbaum JM, Masters CL, Grzeschik K-H, Multhaup G, Beyreuther K, Müller-Hill B (1987) The precursor of Alzheimer's disease amyloid A4 protein resembles a cell-surface receptor. Nature 325:733-736.

Kawarabayashi T, Shoji M, Harigaya Y, Yamaguchi H, Hirai S (1991) Amyloid $B / A 4$ protein precursor is widely distributed in both the central and peripheral nervous systems of the mouse. Brain Res 552: $1-7$.

Kitaguchi N, Takahashi Y, Tokushima Y, Shiojiri S, Ito H (1988) Novel precursor of Alzheimer's disease amyloid protein shows protease inhibitory activity. Nature 331:530-532.

König G, Mönning U, Czech C, Prior R, Banati R, Schreiter-Gasser U, Bauer J, Masters CL, Beyreuther K (1992) Identification and differential expression of a novel alternative splice isoform of the $3 \mathrm{~A} 4$ amyloid precursor protein (APP) mRNA in leukocytes and brain microglial cells. J Biol Chem 267:10804-10809.

Koo EH, Sisodia SS, Archer DR, Martin LJ, Weidemann A, Beyreuther K, Fischer P, Masters CL, Price DL (1990) Precursor of amyloid protein in Alzheimer disease undergoes fast anterograde axonal transport. Proc Natl Acad Sci USA 87:1561-1565.

Lee MK, Tuttle JB, Rebhun LI, Cleveland DW, Frankfurter A (1990) The expression and posttranslational modification of a neuron-specific $\beta$-tubulin isotype during chick embryogenesis. Cell Motil Cytoskel 17:118-132.

Lee MK, Xu Z, Wong PC, Cleveland DW (1993) Neurofilaments are obligate heteropolymers in vivo. J Cell Biol 122:1337-1350.

Maeda N, Matsui F, Oohira A (1992) A chondroitin sulfate proteoglycan that is developmentally regulated in the cerebellar mossy fiber system. Dev Biol 151:564-574.

Martin LJ, Sisodia SS, Koo EH, Cork LC, Dellovade TL, Weidemann A, Beyreuther K, Masters C, Price DL (1991) Amyloid precursor protein in aged nonhuman primates. Proc Natl Acad Sci USA 88: 1461-1465.

Masliah E, Mallory M, Deerinck T, DeTeresa R, Lamont S, Miller A, Terry RD, Carragher B and Ellisman M (1993) Re-evaluation of the structural organization of neuritic plaques in Alzheimer's disease. $\mathbf{J}$ Neuropathol Exp Neurol 52:619-632.

Masters CL, Simms G, Weinman NA, Multhaup G, McDonald BL, Beyreuther K (1985) Amyloid plaque core protein in Alzheimer disease and Down syndrome. Proc Natl Acad Sci USA 82:4245 4249.

Mizushima S, Nagata S (1990) pEF-BOS, a powerful mammalian expression vector. Nucleic Acids Res 18:5322.

Okuda R, Uchida K, Tateyama S, Yamaguchi R, Nakayama H, Goto N (1994) The distribution of amyloid beta precursor protein in canine brain. Acta Neuropathol (Berl) 87:161-167.

Ouimet CC, Baerwald KD, Gandy SE, Grecngard P (1994) Immunocytochemical localization of amyloid precursor protein in rat brain. $\mathrm{J}$ Comp Neurol 244-260.

Ponte P, Gonzalez-DeWhitt P, Schilling J, Miller J, Hsu D, Greenberg B, Davis K, Wallace W, Lieberburg I, Fuller F, Cordell B (1988) A new A4 amyloid mRNA contains a domain homologous to serine proteinase inhibitors. Nature 331:525-532.

Sandbrink R, Masters CL, Beyreuther K (1994) Similar alternative splicing of a non-homologous domain in $\beta A 4$-amyloid protein precursor-like proteins. J Biol Chem 269:14227-14234.

Shivers BD, Hilbich C, Multhaup G, Salbaum M, Beyreuther K, Seeburg PH (1988) Alzheimer's disease amyloidogenic glycoprotein: expression pattern in rat brain suggests a role in cell contact. EMBO J 7:1365-1370.

Sisodia SS, Koo EH, Beyreuther K, Unterbeck A, Price DL (1990) Evidence that $\beta$-amyloid protein in Alzheimer's disease is not derived by normal processing. Science 248:492-495.

Sisodia SS, Koo EH, Hoffman PN, Perry G, Price DL (1993) Identification and transport of full-length amyloid precursor proteins in rat peripheral nervous system. J Neurosci 13:3136-3142.

Slunt HH, Thinakaran G, von Koch C, Lo ACY, Tanzi RE, Sisodia SS (1994) Expression of a ubiquitous, cross-reactive homologue of the mouse $\beta$-amyloid precursor protein (APP). J Biol Chem 269:26372644.

Sprecher CA, Grant FJ, Grimm G, O'Hara PJ, Norris F, Norris K, Foster DC (1993) Molecular cloning of the cDNA for a human amyloid precursor protein homolog: evidence for a multigene family. Biochemistry 32:4481-4486.

Tanzi RE, McClatchey AI, Gusella JF (1988) Molecular genetics of the Alzheimer's amyloid peptide precursor gene. In: The molecular biology of Alzheimer's disease (Finch CE, Davies P eds), pp 95-100. New York: Cold Spring Harbor Laboratory.

Thinakaran G, Sisodia SS (1994) Amyloid precursor-like protein 2 (APLP2) is modified by the addition of chondroitin sulfate glycosaminoglycan at a single site. J Biol Chem 269:220099-22104.

Thinakaran G, Slunt HH, Sisodia SS (1995) Novel regulation of chondroitin sulfate glycosaminoglycan modification of amyloid precursor protein and its homologue, APLP2. J Biol Chem, 270:16522-16525. 
Trapp BD, Hauer PE (1994) Amyloid precursor protein is enriched in radial glia: implications for neuronal development. J Neurosci Res 37:538-550.

Wasco W, Bupp K, Magendantz M, Gusella JF, Tanzi RE, Solomon F (1992) Identification of a mouse brain CDNA that encodes a protein related to the Alzheimer disease-associated amyloid-beta-protein precursor. Proc Natl Acad Sci USA 89:10758-10762.
Wasco W, Gurubhagavatula S, Paradis MD, Romano DM, Sisodia SS, Hyman BT, Neve RL, Tanzi RE (1993) Isolation and characterization of APLP2 encoding a homologue of the Alzheimer's associated amyloid $\beta$ protein precursor. Nature Genet 5:95-99.

Wight TN, Kinsella MG, Qwarnström EE (1992) The role of proteoglycans in cell adhesion, migration and proliferation. Curr Opin Cell Biol 4:793-801. 